\title{
POTENSI AKTIVITAS PENGHAMBATAN MIKROBIA DAN AKTIVITAS ANTIOKSIDAN PADA MINUMAN COKELAT DENGAN PENAMBAHAN GARAM MASALA
}

\section{POTENTIAL OF ANTIMICROBIAL AND ANTIOXIDANT ACTIVITIES ON CHOCOLATE BEVERAGE WITH GARAM MASALA ADDITION}

\author{
Anjar Ruspita Sari*, Ratih Hardiyanti, Sri Wijanarti \\ Sarjana Terapan Pengembangan Produk Agroindustri, Departemen Teknologi Hayati dan Veteriner \\ Sekolah Vokasi \\ Universitas Gadjah Mada, Indonesia \\ Jl. Yacaranda, Sekip Unit I, Bulaksumur, Condongcatur, Depok, Sleman, D.I.Y \\ "Email korespondensi: anjar_ruspita@ugm.ac.id
}

Diterima 01-09-2020, diperbaiki 23-10-2020, disetujui 13-11-2020

\begin{abstract}
Chocolate derivatives, such as beverage, is popularly developed with various flavor enrichment. It is experiencing growth in the market, including bottled ready-to-drink chocolate beverage, chocolate powder drink, and chocolate beverage that is widely available at chocolate cafés or stalls. Health benefits of various spices have been well investigated, but not have been widely used in the development of chocolate beverage. Therefore, the functional properties of spicy chocolate prepared with the addition of spices, garam masala is one of the spices, needed to be investigated. The objectives of the study were to evaluate the effects of garam masala addition on chocolate beverage to antimicrobial activity, antioxidant activity, and total phenolic content. Various formulas of garam masala addition (0.01-0.10\%) were evaluated the functional properties to ensure the benefits of chocolate beverage enhanced with garam masala. The result showed that the addition of garam masala in chocolate beverage could increase the antimicrobial activity especially to inhibit negative gram bacteria (Salmonella thypii and Eschericia coli) with minimum concentration at $0.08 \%$. Furthermore, garam masala addition increased antioxidant activity and total phenolic content with minimum concentration at $0.04 \%$.
\end{abstract}

Keywords: Antimicrobial, antioxidant, spicy chocolate

\begin{abstract}
ABSTRAK
Produk turunan cokelat sebagai produk minuman marak dikembangkan dengan penambahan berbagai varian rasa. Berbagai produk bermunculan di pasar, seperti minuman cokelat siap minum, minuman cokelat bubuk, dan minuman cokelat yang banyak tersedia di kafe. Rempah-rempah telah dilaporkan memiliki banyak manfaat kesehatan namun belum banyak digunakan dalam pengembangan minuman cokelat. Minuman cokelat dengan rasa pedas yang dihasilkan dengan penambahan rempah-rempah, yaitu garam masala, perlu diteliti sifat fungsionalnya. Tujuan penelitian ini adalah untuk mempelajari penambahan garam masala pada minuman cokelat terhadap potensi sifat penghambatan mikrobia, aktivitas antioksidan, dan total fenol. Sepuluh formula penambahan garam masala $(0.01-0,10 \%)$ dievaluasi sifat fungsionalnya untuk mengetahui keuntungan penambahan garam masala pada minuman cokelat. Hasil penelitian menunjukkan bahwa penambahan garam masala pada
\end{abstract}


minuman cokelat dapat meningkatkan aktivitas penghambatan mikrobia terutama untuk bakteri gram negatif (Salmonella thypii dan Eschericia coli) pada minuman cokelat dengan minimum penambahan konsentrasi garam masala $0.08 \%$. Lebih lanjut, garam masala juga meningkatkan aktivitas antioksidan dan total kandungan fenol terdeteksi pada minuman cokelat dengan minimum penambahan konsentrasi garam masala $0.04 \%$.

Kata Kunci: Antimikrobia, antioksidan, cokelat pedas

\section{PENDAHULUAN}

Indonesia merupakan negara penghasil kakao ketiga tertinggi di dunia setelah Pantai Gading dan Ghana. Meskipun demikian, konsumsi produk olahan kakao seperti cokelat batang, cokelat bubuk dan minuman cokelat oleh masyarakat masih tergolong rendah. Konsumsi minuman kakao Indonesia dapat dibedakan menjadi tiga jenis, yaitu cokelat bubuk, minuman coklat dalam botol, dan minuman cokelat siap minum yang saat ini menjamur di kafe-kafe maupun gerai minuman dengan berbagai varian rasa. Perkembangan konsumsi cokelat bubuk dan cokelat instan berfluktuatif dari tahun 2002-2015. Berdasarkan peramalan dengan time series menggunakan analisis trend didapatkan konsumsi produk turunan kakao dalam bentuk coklat instan adalah $39 \mathrm{~g} /$ kapita, sedangkan konsumsi produk turunan kakao dalam bentuk coklat bubuk adalah 28,9 kg/kapita pada tahun 2015 (Siagan, 2016). Meskipun Indonesia tergolong sebagai penghasil kakao terbesar, industri pengolahan kakao yang dimiliki termasuk kecil apabila dibandingkan dengan jumlah produksi bahan mentah dalam bentuk biji kakao. Sebagai upaya meningkatkan sektor industri pengolahan kakao, pada tahun 2008 pemerintah memulai inisiasi kebijakan hilirisasi kakao. Lebih lanjut, kebijakan pemerintah melalui Peraturan Menteri Keuangan Nomor 67/PMK.011/2010 tentang penetapan barang ekspor yang dikenakan bea keluar dan tarif bea keluar berdampak pada peningkatan industri kakao nasional, penurunan volume ekspor biji kakao, dan peningkatan ekspor kakao olahan.

Minuman berbasis cokelat saat ini tidak hanya dapat dinikmati oleh konsumen golongan menengah ke atas, namun juga sebagai gaya hidup yang marak pada anak muda yang berasal dari berbagai golongan. Hal ini mendorong perkembangan berbagai formulasi minuman cokelat untuk memenuhi selera konsumen. Formulasi minuman cokelat yang dikembangkan oleh peneliti tidak hanya memperhatikan soal variasi rasa, namun juga memperhatikan karakeristik fungsionalnya seperti kandungan antioksidan, sifat eliksir, serta antimikrobia. Sebagai contoh penambahan minuman cokelat dengan koloid kayu manis untuk meningkatkan kandungan antioksidan dan stabilitasnya (Muhammad et al., 2019); penambahan krimmer non hasil ternak sebagai imunomodulator (Rosniati, 2016); penambahan ekstrak kayu secang, ekstrak serai, dan ekstrak jahe untuk meningkatkan penerimaan konsumen (Utari, 2015); serta penambahan minyak bekatul dan ekstrak meniran untuk meningkatkan sifat antioksidannya (Rachman et al., 2012). Lebih lanjut, minuman cokelat yang ditambahkan dengan cabe dan kayu manis untuk menghasilkan rasa pedas juga sudah dilakukan oleh suku Aztecs ratusan tahun yang lalu (Verna, 2013).

Penggunaan garam masala dalam berbagai hidangan cukup umum dilakukan terutama untuk masakan dengan gaya India dan Timur Tengah yang mulai diminati oleh masyarakat. Terbukti dari banyaknya restoran yang menyajikan khas makanan Timur Tengah tumbuh di berbagai wilayah Yogyakarta. Garam masala juga sudah banyak tersedia di toko-toko online maupun offline di supermarket. Garam dalam Bahasa Hindi berarti panas, sedangkan masala berarti ramuan, sehingga garam masala dapat diartikan sebagai ramuan 
yang pedas (Shukla \& Nagendra, 2018). Meskipun komposisi garam masala bervariasi berdasarkan daerah asalnya, namun secara umum garam masala mengandung merica, temulawak, cengkih, daun kari (ruku-ruku), kayu manis, bunga pekak, dan biji pala. Seluruh bahan dihaluskan dan dijadikan sebagai bumbu. Penggunaan rempah-rempah tidak hanya terbatas pada masakan namun juga digunakan dalam pembuatan minuman untuk lebih menarik konsumen. Terlepas dari aroma dan rasa yang dihasilkan, rempah-rempah juga memiliki keuntungan dari segi kesehatan yang sudah lazim dijumpai pada produk teh herbal, seperti penambahan garam masala pada teh hitam yang diperhitungkan sebagai produk pereda demam dan batuk (Ochanda, et al., 2015). Antioksidan yang terkandung dalam rempah-rempah sebagai bahan dasar garam masala adalah komponen fenol, tannin, alkaloid, diterpene fenol, dan flavonoid (Yashin et al., 2017). Basu et al., (2016) menambahkan bahwa garam masala juga memiliki sifat antioksidan dan antimikrobia yang dapat menghambat aktivitas bakteri gram negatif khususnya Stapylococcus aureus dan Bacillus cereus. Terbatasnya pustaka mengenai pemanfaatan garam masala pada produk minuman menjadi latar belakang untuk mengkaji lebih jauh efek penambahan garam masala dengan berbagai konsentrasi terhadap sifat antimikrobia, antioksidan, dan total kandungan fenol. Penambahan garam masala pada minuman cokelat diharapkan akan memberikan rasa dan aroma khas, menambah salah satu varian rasa minuman cokelat, serta dapat bermanfaat bagi tubuh seperti menghangatkan tubuh dan berperan sebagai antimikrobia dan antioksidan.

\section{METODE PENELITIAN}

\section{Alat dan Bahan}

Alat yang digunakan dalam penelitian meliputi timbangan digital FSAR210 (Fujitsu, Jepang), gelas cawan, spatula, kertas kopi saring untuk menyiapkan formula minuman cokelat yang ditambahkan garam masala. Alat yang digunakan untuk analisis aktivitas antioksidan dan total kandungan fenol, meliputi peralatan gelas (labu ukur, pipet volume, gelas ukur, dan tabung reaksi) (Pyrex, Jerman) dan Spetrofotometer Genesys 20 model 400/1 (Thermo Fisher, USA). Sedangkan alat yang digunakan untuk pengujian penghambatan mikrobia adalah cawan petri (Pyrex, Jerman) dan Inkubator (Memmert, Jerman).

Bahan penelitian utama yang digunakan dalam penelitian adalah bubuk cokelat murni (100\% bubuk cokelat) yang berasal dari Kampung Cokelat Blitar, Jawa Tengah. Garam masala yang digunakan adalah garam masala dengan merek Cairo food yang tersedia di pasar online yang dapat langsung digunakan. Adapun komposisi garam masala terdiri dari biji ketumbar, adas manis, cabai merah, lada hitam, kapulaga hijau, cengkeh, kayu manis, daun salam, jahe putih, biji pala, kapulaga putih, jinten, serta anti kempal yang berasal dari beras putih.

\section{Prosedur Formulasi Minuman Cokelat Dengan Penambahan Garam Masala}

Formulasi minuman cokelat mengikuti langkah yang dilakukan oleh Hardiyanti et al., (2020). Formulasi dilakukan dengan mengkombinasikan garam masala pada minuman bubuk cokelat tanpa penambahan gula maupun krim. Garam masala ditambahkan dengan konsentrasi $0.1 \%$ $0.10 \%$ yang dibungkus dalam kertas saring. Cokelat bubuk sebanyak $5 \mathrm{~g}$ yang telah ditambahkan gram masala dilarutkan dengan $100 \mathrm{ml}$ air panas suhu $90 \pm 5^{\circ} \mathrm{C}$. Selanjutnya, garam masala direndam pada minuman cokelat selama 30 menit dalam wadah tertutup untuk mempertahankan suhu minuman cokelat dan mengoptimalkan ekstraksi komponen garam masala pada minuman cokelat. Terakhir, kertas saring yang berisikan garam masala dipisahkan dari minuman cokelat dan selanjutnya diuji potensi 
aktivitas penghambatan mikrobia serta antioksidan.

\section{Pengukuran potensi aktivitas penghambatan mikrobia dan antioksi dan Minuman Cokelat Pedas}

\section{Penentuan Aktivitas Antimikrobia}

Mikrobia uji yang digunakan dalam pengujian aktivitas antimikrobia adalah biakan murni Salmonella thypii dan Eschericia coli dari Laboratorium Mikrobiologi, Pusat Antar Universitas (PAU), Universitas Gadjah Mada. Peremajaan suspensi bakteri dibuat dengan mengambil 1 ose biakan ke dalam tabung reaksi yang berisi $0.9 \mathrm{NaCl}$ fisiologis steril dan selanjutnya dimasukkan ke dalam inkubator (Memmert, Jerman) selama 24 jam pada suhu $37^{\circ} \mathrm{C}$. Pengujian antimikrobia dilakukan secara triplikasi dengan metode difusi kertas cakram yang dilakukan oleh Muharni, et al. (2017) yang dimodifikasi pada cawan petri yang dibagi menjadi 4 juring untuk pengamatan. Selanjutnya kertas cakram yang telah direndam pada minuman cokelat pedas pada berbagai konsentrasi diletakkan di atas media NA yang berisi bakteri. Cawan petri diinkubasi selama 24 jam, suhu $37^{\circ} \mathrm{C}$ pada inkubator (Memmert, Jerman) dan pengamatan pertumbuhan bakteri dengan mengukur zona jernih di sekitar area kertas cakram. Kontrol positif menggunakan minuman cokelat tanpa penambahan garam masala, sedangkan control negatif menggunakan aquades.

\section{Penentuan Potensi Antioksidan (Kandungan Total Fenol dan Aktivitas Antioksidan)}

\section{Pengukuran Kandungan Total Fenol}

Kandungan total fenol pada minuman coklat pedas dianalisis dengan menggunakan metode Follin-ciocalteu yang telah dimodifikasi oleh Sari dan Hardiyanti (2013). Sebanyak $0.05 \mathrm{ml}$ minuman cokelat pedas dimasukkan ke dalam tabung reaksi, selanjutnya ditambahkan $1 \mathrm{ml}$ etanol, $5 \mathrm{ml}$ aquades, dan $0.5 \mathrm{ml}$ reagen Follin-ciocalteu $(50 \%)$. Campuran dihomogenkan menggunakan vortex dan setelah 5 menit ditambahkan $1 \mathrm{ml} \mathrm{Na}_{2} \mathrm{CO}_{3}(5 \%)$ dan dihomogenkan menggunakan vortex. Reaksi campuran diinkubasi di tempat gelap selama 60 menit dan ditera nilai absorbansinya menggunakan spektrofotometer (Thermo Scientific Genesys, Inggris) pada $725 \mathrm{~nm}$. Kurva standar untuk menentukan kandungan total fenol pada minuman cokelat pedas dibuat dengan cara yang sama, namun sampel diganti dengan asam galat dengan konsentrasi $0.01,0.02,0.03,0.04$, dan $0.05 \%$. Total kandungan fenol pada minuman coklat pedas dinyatakan dalam $\mathrm{mg} / \mathrm{L}$ minuman.

\section{Penentuan Aktifitas Antioksidan}

Aktifitas antioksidan pada minuman cokelat pedas diukur berdasarkan kemampuan minuman cokelat pedas untuk menangkap radikal bebas (radical scavenging activity) reagen DPPH mengikuti metode yang dimodifikasi oleh Sari \& Hardiyanti (2013). Reagen DPPH (400 $\mu \mathrm{M}$ dalam etanol) sebanyak $1 \mathrm{ml}$ dan $3 \mathrm{ml}$ etanol ditambahkan dalam tabung reaksi yang dibungkus aluminium foil, selanjutnya ditambahkan $0.1 \mathrm{ml}$ minuman coklat pedas yang telah dilakukan pengenceran10x terlebih dahulu. Campuran dihomogenkan menggunakan vortex dan diinkubasi selama 20 menit pada ruangan gelap untuk kemudian ditera nilai absorbansi larutan pada panjang gelombang $517 \mathrm{~nm}$ menggunakan spektrofotometer (Thermo Scientific Genesys, Inggris). Aktifitas antioksidan minuman cokelat pedas dinyatakan dalam $\%$ penghambatan.

$\%$ penghambatan $=$

$\frac{\text { Absorbansi blanko-Absorbansi sampel }}{x 100}$

\section{Analisis Data \\ Analisis data yang diperoleh dilakukan secara statistik menggunakan software SPSS versi 22 untuk mengetahui tingkat signifikansi potensi penghambatan mikrobia dan antioksidan pada minuman}


cokelat yang telah ditambahkan garam masala $(\mathrm{p}<0.05)$.

\section{HASIL DAN PEMBAHASAN}

\section{Potensi Penghambatan Mikrobia pada Minuman Cokelat Pedas}

Aktivitas antimikrobia menunjukkan kemampuan bahan untuk menghambat pertumbuhan bakteri. Bakteri uji yang digunakan dalam penelitian ini adalah Salmonella thypii dan Eschericia coli yang merupakan bakteri gram negatif yang dapat menyebabkan permasalahan pada kesehatan manusia (bakteri patogen) (Muharni, et. al., 2017). Tabel 1 menyajikan potensi penghambatan mikrobia dengan penambahan garam masala $(0.01-0.10 \%)$ pada minuman cokelat.

Tabel 1. Potensi penghambatan mikrobia pada minuman cokelat dengan penambahan garam masala

\begin{tabular}{ccc}
\hline \multirow{2}{*}{$\begin{array}{c}\text { Konsentrasi } \\
\text { garam masala }\end{array}$} & \multicolumn{2}{c}{ Zona bening $(\mathrm{mm})$} \\
\cline { 2 - 3 } & $\begin{array}{c}\text { Salmonella } \\
\text { thypii }\end{array}$ & Eschericia coli \\
\hline 0.01 & $8 \pm 0.5^{\mathrm{bB}}$ & $6 \pm 0.1^{\mathrm{bA}}$ \\
0.02 & $8 \pm 0.1^{\mathrm{bB}}$ & $7 \pm 0.0^{\mathrm{cA}}$ \\
0.03 & $8 \pm 0.0^{\mathrm{bB}}$ & $7 \pm 0.3^{\mathrm{cA}}$ \\
0.04 & $8 \pm 0.2^{\mathrm{bB}}$ & $7 \pm 0.1^{\mathrm{cA}}$ \\
0.05 & $8 \pm 0.1^{\mathrm{bA}}$ & $8 \pm 0.5^{\mathrm{dA}}$ \\
0.06 & $8 \pm 0.2^{\mathrm{bB}}$ & $7 \pm 0.0^{\mathrm{cA}}$ \\
0.07 & $8 \pm 0.1^{\mathrm{bB}}$ & $7 \pm 0.2^{\mathrm{cA}}$ \\
0.08 & $9 \pm 0.1^{\mathrm{cB}}$ & $8 \pm 0.5^{\mathrm{dA}}$ \\
0.09 & $14 \pm 0.5^{\mathrm{dB}}$ & $9 \pm 0.2^{\mathrm{eA}}$ \\
0.1 & $15 \pm 0.2^{\mathrm{eB}}$ & $11 \pm 0.2^{\mathrm{fA}}$ \\
+ & $8 \pm 0.0^{\mathrm{bB}}$ & $6 \pm 0.5^{\mathrm{aA}}$ \\
- & $0^{\mathrm{aA}}$ & $0^{\mathrm{aA}}$ \\
\hline
\end{tabular}

Keterangan: (+) minuman cokelat tanpa penambahan garam masala; (-) aquades

Perbedaan subscript huruf kecil pada masing-masing bakteri menunjukkan rata-rata nilai yang yang berbeda secara signifikan $(\mathrm{p}<0.05)$ dan perbedaan subscript huruf kapital pada masing-masing konsentrasi garam masala menunjukkan rata-rata yang berbeda secara signifikan $(\mathrm{p}<0.05)$

Berdasarkan Tabel 1, penambahan garam masala pada minuman cokelat lebih efektif untuk menghambat pertumbuhan bakteri Salmonella thypii dibandingkan untuk menghambat bakteri E. coli. Hal ini ditunjukkan dengan zona bening yang dihasilkan pada penghambatan bakteri Salmonella thypii yang lebih lebar dibandingkan zona bening yang dihasilkan pada penghambatan bakteri E. coli. Meskipun demikian, penambahan garam masala pada minuman cokelat dapat meningkatkan aktivitas antimikrobia secara signifikan setelah penambahan garam masala dengan konsentrasi $0.08 \%$ baik dalam penghambatan bakteri Salmonella thypii maupun bakteri E. coli. Diameter penghambatan minuman cokelat pedas yang ditambahkan garam masala $0.08 \%$ setara dengan penghambatan ekstrak kulit bawang merah konsentrasi $50 \%$ pada bakteri Salmonella thypii dan bakteri E. coli yang dilakukan Octaviani et al. (2019). Lebih lanjut, zona penghambatan minuman cokelat pedas yang ditambahkan garam masala $0.08 \%$ setara dengan ekstrak alangalang konsentrasi $10 \%$ yang dilakukan oleh Mulyadi et al. (2013). Oleh karena itu, minuman cokelat pedas yang dibuat dengan garam masala mempunyai potensi untuk menghambat mikrobia.

\section{Potensi Antioksidan (Kandungan Total Fenol dan Aktivitas Antioksidan) pada Minuman Cokelat Pedas}

Potensi antioksidan yang terdapat pada minuman cokelat pedas diukur menggunakan kandungan total fenol dan aktivitas antioksidannya. Total komponen fenol pada minuman cokelat pedas didapatkan dari persamaan kurva standar asam galat pada konsentrasi 0.01, 0.02, 0.03, 0.04, dan 0.05\% (Persamaan 2). 
$\mathrm{y}=0.72 \mathrm{x}+0.01$

Komponen fenol yang diukur pada minuman cokelat pedas adalah komponen fenol keseluruhan yang terkandung di dalamnya, sehingga disebut sebagai total fenol. Total fenol juga mempunyai kemampuan sebagai antioksidan, sehingga perlu diketahui berapa aktivitas antioksidan dari total fenol yang terkandung dalam minuman cokelat pedas. Hasil pengujian total fenol dan aktivitas antioksidan disajikan pada Gambar 1.

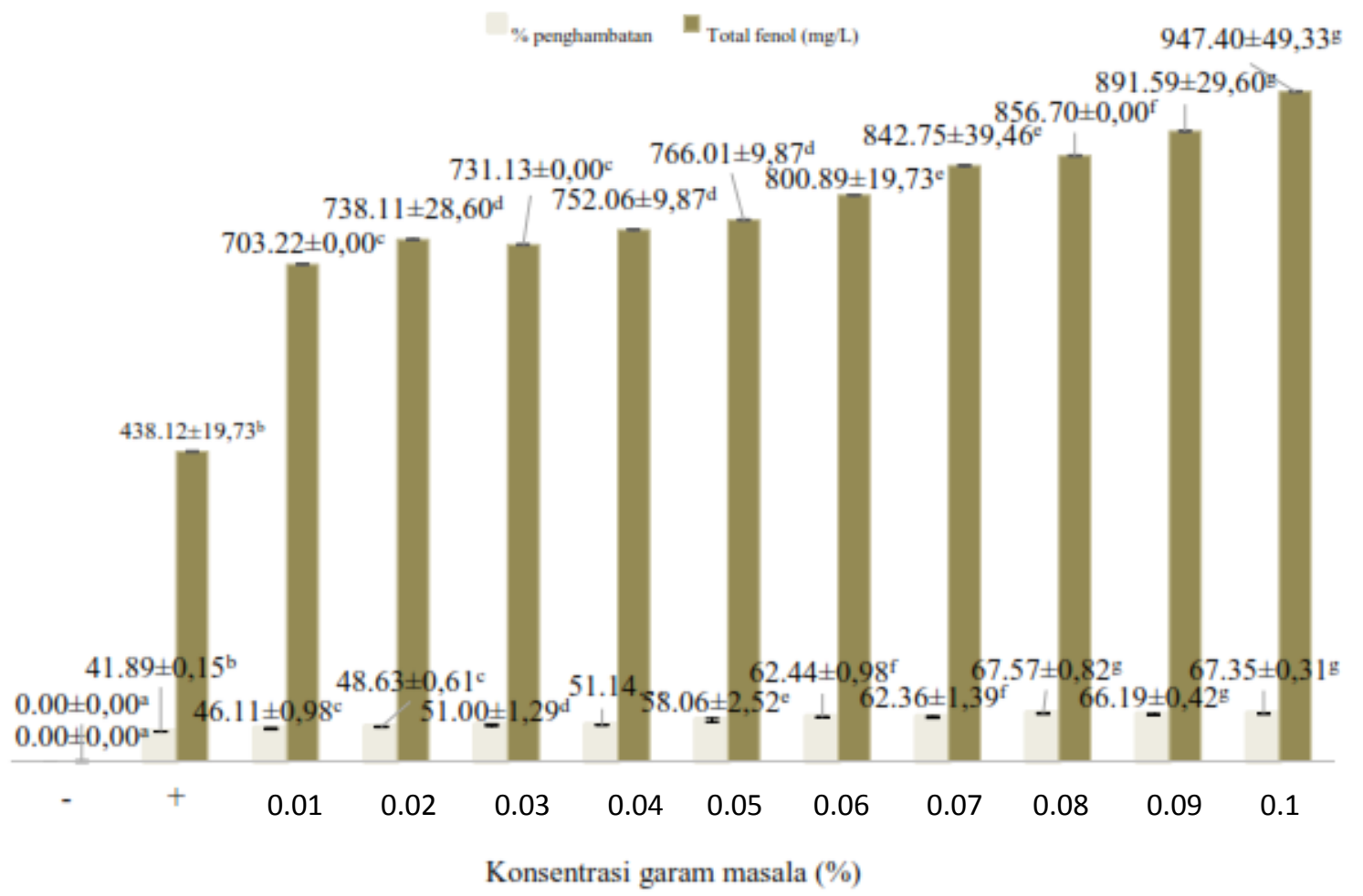

Keterangan: (+) minuman cokelat tanpa penambahan garam masala (-) aquades

Perbedaan subscript huruf kecil pada masing-masing kolom menunjukkan rata-rata nilai yang yang berbeda secara signifikan $(\mathrm{p}<0.05)$

Gambar 1. Total Komponen Fenol dan Aktivitas Antioksidan Minuman Cokelat Pedas

Secara umum, total fenol dalam minuman cokelat pedas lebih tinggi secara signifikan $(\mathrm{p}<0.05)$ dibandingkan dengan minuman cokelat tanpa penambahan garam masala. Sesuai penemuan Yashin et al. (2017), rempah-rempah dalam garam masala memiliki komponen fenol sebagai antioksidan. Peningkatan kandungan total fenol pada minuman cokelat yang ditambahkan garam masala tidak berbeda secara nyata $(\mathrm{p}<0.05)$ pada konsentrasi garam masala $0.01-0.04 \%$, selanjutnya kandungan total fenol meningkat secara signifikan pada peningkatan kandungan penambahan garam masala $0.05-0.10 \%$. Sedangkan, aktivitas antioksidan pada minuman cokelat pedas lebih tinggi secara signifikan $(\mathrm{p}<0.05)$ dibandingkan dengan aktivitas antioksidan pada minuman cokelat tanpa penambahan garam masala. Aktivitas antioksidan pada minuman cokelat pedas tidak berbeda secara nyata $(\mathrm{p}<0.05)$ pada konsentrasi $\quad 0.01-0.04 \%$, selanjutnya aktivitas antioksidan akan meningkat secara signifikan $(\mathrm{p}<0.05)$ pada konsentrasi $0.05 \%$ dan selanjutnya tidak ada perbedaan secara nyata $(\mathrm{p}<0.05)$ pada konsentrasi 0.06$0.10 \%$. Aktivitas antioksidan yang dimiliki oleh minuman cokelat yang ditambahkan $0.04 \%$ garam masala sebanding dengan aktivitas antiosidan pada minuman cokelat yang ditambahkan ekstrak meniran dan bekatul dengan formula 1:3 yang dilakukan oleh Rachman et al., (2012). 


\section{KESIMPULAN}

Berdasarkan hasil dan pembahasan maka dapat disimpulkan bahwa penambahan garam masala pada minuman cokelat dapat meningkatkan $(p<0.05)$ sifat fungsionalitas minuman cokelat yaitu aktivitas antimikrobia dan aktivitas antioksidan. Aktivitas antimikrobia pada minuman cokelat dapat meningkat secara signifikan $(\mathrm{p}<0.05)$ pada penambahan konsentrasi garam masala minimum $0.08 \%$. Sedangkan, total kandungan fenol dan aktivitas antioksidan meningkat secara signifikan $(p<0.05)$ dengan penambahan konsentrasi garam masala minimum $0.04 \%$.

\section{UCAPAN TERIMA KASIH}

Terima kasih diucapkan untuk Sekolah Vokasi, Universitas Gadjah Mada yang telah mendukung penelitian melalui hibah penelitian Dana Masyarakat Sekolah Vokasi.

\section{DAFTAR PUSTAKA}

Basu, T., Bhattacharyya, S., Maitra, S., \& Rai, C. 2016. Evaluation of antioxidant and antimicrobial activities of Garam Masala, an Indian spice blend, and its' components In Vitro. Der Pharmacia Lettre, 8(20), 110-116.

Hardiyanti, R., Sari, A. R., Norsita, D. I., \& Bachtiar, W. F. 2020. The Effect of Garam Masala Levels Addition on Chocolate Based Functional Beverage. Journal of Applied Food Technology, 7(1), 5-8.

Muhammad, D. R. A., Gonzalez, C. G., Sedaghat Doost, A., Van de Walle, D., Van der Meeren, P., \& Dewettinck, K. 2019. Improvement of Antioxidant Activity and Physical Stability of Chocolate Beverage Using Colloidal Cinnamon Nanoparticles. Food and
Bioprocess Technology, 976-989.

Muharni, Fitrya, \& Farida, S. 2017. Uji Aktivitas Antibakteri Ekstrak Etanol Tanaman Obat Suku Musi di Kabupaten Musi Banyuasin , Sumatera Selatan Antibacterial Assay of Ethanolic Extract Musi Tribe Medicinal Plant. Jurnal Kefarmasian Indonesia, 7(2), 127-135.

Mulyadi, M., Wuryanti, \& S, P. R. 2013. Konsentrasi Hambat Minimum (KHM) Kadar Sampel Alang-Alang (Imperata cylindrica) dalam Etanol Melalui Metode Difusi Cakram. Chem Info, 1(1). 35-42.

Ochanda, S. O., Wanyoko, J. K., \& Ruto, H. K. 2015. Antioxidant Capacity and Consumer Acceptability of Spiced Black Tea. Journal of Food Research, 4(6): 104-112.

Octaviani, M., Fadhli, H., \& Yuneistya, E. 2019. Uji Aktivitas Antimikroba Ekstrak Etanol dari Kulit Bawang Merah (Allium cepa L.) dengan Metode Difusi Cakram. Pharmaceutical Sciences and Research, 6(1): 62-68.

Rachman, P. H., Priskila, P., Damayanthi, E., \& Priosoeryanto, B. P. 2012. Minuman Tinggi Aktivitas Antioksidan Berbahan Dasar Alami Minyak Bekatul Padi (Oryzae sativa) dan Ekstrak Meniran (Phyllanthus niruri). Jurnal Gizi Dan Pangan, 7(3): 189-196.

Rosniati, R. 2016. Pengembangan Minuman Instan Cokelat- Kedelai Sebagai Minuman Kesehatan. Jurnal Industri Hasil Perkebunan, 11(1): 3342.

Sari, A. R., \& Hardiyanti, R. 2013. Antioxidant Level and Sensory of Dragon Fruit (Hylocereus undatus) Peel Tea Infusion Made by Partially 
Fermented Process. Agroindustrial Journal, 2(1): 63-68.

Shukla, A., \& Nagendra, Y. 2018. Role of Indian Spices in Indian History. International Journal of Management Research \& Review, 8(11): 1-6.

Siagan, V. J. 2016. Outlook Kakao (L. Nuryati \& A. Yasin (eds.)). Pusat Data dan Sistem Informasi Pertanian.

Utari, E. 2015. Karakretistik Kimia dan
Sensori Minuman Cokelat (Theobroma cacao) - Rempah Serta Stabilitas Polifenol dan Aktivitas Antioksidan. 1-62.

Verna, R. 2013. The history and science of chocolate. Malaysian Journal of Pathology, 35(2): 111-121.

Yashin, A., Yashin, Y., Xia, X., \& Nemzer, B. 2017. Antioxidant activity of spices and their impact on human health: A review. Antioxidants, 6(3): 1-18. 